Ludlow; certainly they will not be so far out as if they continued to use the base of the $P$. ludensis Zone as the base of the Ludlovian.

C. H. Holland,

R. B. RICKARDS,

Department of Geology,

Trinity College, DuBLIN, 2.

24th April, 1967.
P. T. WARREN,

Institute of Geological Sciences, Ring Road Halton, LEEDS, 15.

\title{
IGNIMBRITE IN MALAYA
}

SIR,- $-\mathrm{Mr}$. Aw is to be congratulated on his recognition of the Temangan dyke as an ignimbrite (Geol. Mag., 104 (1), 13-14), which is indeed the first published record of this rock type in Malaya, although the present writer has previously mapped ignimbrites (first identified by Flinter, personal communication) over some square miles in the south of the country, in Johore state. Unfortunately the bulletin on this area, written in 1962, still awaits publication (Burton, in manuscript). The Johore ignimbrites are of the welded tuff variety rather than the sillar kind found at Temangan.

Attention is drawn by Aw to an error on the 1963 geological map of Malaya (Alexander, 1965) wherein the Temangan dyke is represented as quartz porphyry. In fact other, more extensive, areas of quartz porphyry in this map are now similarly known to be of volcanic character. During reconnaissance mapping, officers of the Malayan Geological Survey used the term quartz porphyry in a purely descriptive sense to refer to rocks comprised of a fine matrix within which phenocrysts of feldspar are prominent. Although not made clear in the legend, it is this usage which has been perpetuated in the 1963 map. Owing to the intense tropical weathering of many exposures, particularly in low-lying areas in the states of Pahang and Johore, the true nature of these rocks long remained obscure. For some time it was believed that many of them were of metasomatic genesis, comprising recrystallized sediments bearing porphyroblasts of quartz, plus feldspar. Later it became evident to the writer that the quartz porphyries of the Rompin Forest Reserve in Pahang are volcanic in nature and that their large quartzes, which give the impression of "growing" in situ, are actually in various stages of corrosion. Some, at least, of these rocks are probably ignimbrites also. Geologists working in other areas in Malaya have arrived, independently, at similar conclusions and it is now realized that, like the Temangan dyke, many of the "intrusive quartz porphyries" shown in the 1963 map, particularly in Pehang and in Perak, are in reality rhyolitic and rhyodacitic volcanic rocks.

Aw considers that the Temangan ignimbrite plugs an old feeding fissure. It is significant that this feature has an almost rectilinear trace throughout its length of 15 miles and is generally within a few hundred yards of the boundary between Aw's "shales and sandstones" and his "Kelantan schists "-a boundary that MacDonald (in manuscript) has shown to be itself approximately straight for some 40 miles. MacDonald has further recorded evidence of faulting and the incidence of iron mineralization at several points along this line of contact between two sedimentary formations of vastly different metamorphic grade. To northward this line passes below an alluvial cover, but when projected to SSE it marks the eastern margin of the Boundary Range granite batholith for 38 miles and corresponds to a narrow zone of outcrop discontinuity for a further 30 miles, at least. At the same time it appears to control the adjacent long straight course of the Lebir river. Moreover, on the earlier 1948 geological map of Malaya (Ingham, 1948) an elongate development of volcanic rocks is indicated extending some 36 miles along the Lebir valley. Whilst much of this volcanic belt has been omitted from the 1963 map, the writer can vouch for the existence of some, at least, of the excluded volcanic rocks. Around Kuala Hawa these closely resemble the welded tuffs of Johore. 
It thus seems clear that the Temangan fissure constitutes part of a major structural element in Malaya, running in a NNW-SSE direction for more than 100 miles. Possibly this is of the nature of a wrench fault, comparable in scale to the great Bok Bak fault recently recognized in the country (Burton, 1965, 1967).

\section{REFERENCES}

AleXander, J. B., 1965. Geological Map of Malaya, 6th edition (Diamond Jubilee). Survey Dept. Malaya No. 67-1964, Geol. Survey Drawing 63-288.

Burton, C. K., 1965. Wrench Faulting in Malaya. J. Geol., 73, 781-798.

1967. Wrench Faulting in Malaya: A Reply. J. Geol., 75, 128-9.

(in manuscript). The Geology and Mineral Resources of the Area covered by New Series Map Sheet 130, Johore. Mem. geol. Surv. Malaysia (Malaya).

Ingham, F. T., 1948. Geological Map of Malaya, 1948. Surv. Dept. Fed. Malaya.

MACDonald, S. (in manuscript). The Geology and Mineral Resources of North Kelantan and North Trengganu. Mem. geol. Surv. Malaysia (Malaya).

Department of Geology, Faculty of SCience,

C. K. Burton.

CHULALONGKORN UNIVERSITY,

BANGKOK, THAILAND.

19 th May, 1966.

\section{HYALOSTELIA ZITTEL AND THE HETERACTINELLIDA}

SIR,-In Dr. B. K. Holdsworth's recent paper (1967) on the dolomitization of siliceous microfossils, the sponge Hyalostelia Zittel is referred to the Heteractinellida, which are described as " an exclusively siliceous group". The nature of their spicules is actually unknown, and grounds exist for thinking them more probably calcareous than siliceous. On the other hand, Hyalostelia is not a member of the Heteractinellida.

The spicules of Heteractinellida were regarded as siliceous by Hinde (1887-1912), but no modern species are known to confirm this. Specimens may occur in calcareous or siliceous preservation, and Wewokella Girty is apparently always calcareous. Finks (1960) has concluded that true heteractinellids are Calcarea. There are no grounds for thinking them related to the Hexactinellida, with which they were grouped by de Laubenfels (1955) in his Hyalospongea, because the characteristic spicules (polyaenes, neoasters) have no counterparts in any known hexactinellid. De Laubenfels stated (1955, p. 93) that " most families of Recent hyalosponges" contain polyactinal microscleres; but, in fact, no such spicules are known from any hexactinellid yet described. The strongest suggestion that the spicules were siliceous is thus the resemblance of polyaenes to demosponge triaenes and their variants (cf. Reid, 1959) ; but this is not conclusive. In contrast, formation of the rays as separate units, now found only in Calcarea, is implied by the suturing of rays at their bases in Chancelloria Walcott (Reid, 1959) and Allonnia Doré and Reid. In addition, a similar suturing, with the rays sharply faceted at their bases as in Allonnia (Doré and Reid, 1965, fig. 1), occurs in triactinal spicules of the living calcareous sponge Leucettusa Dendy $(1929$, pl. 1, figs. $7,10,12)$. Nothing of the kind is recorded from spicules of Hexactinellida or Demospongia. The dependence of the suturing on the mode of formation of the spicules must also rank this evidence higher than any simple resemblance in shape.

This, however, need not conflict with Dr. Holdsworth's conclusions, because Hyalostelia is not heteractinellid, but hexactinellid. When Young and Young (1877) described the type species $H$. smithii as a Hyalonema, 